\title{
Types of responsiveness
}

\author{
John Braithwaite
}

\section{Introduction}

Responsive regulation suggests that governance should be responsive to the regulatory environment and to the conduct of the regulated in deciding whether a more or less interventionist response is needed (Ayres and Braithwaite 1992). From those bare bones, a number of types of responsiveness are considered: pyramidal responsiveness, microresponsiveness, networked responsiveness and meta-regulatory and socialist responsiveness. The Regulatory Institutions Network (RegNet) has been one among many nodes in networks of regulatory practitioners and scholars where these ideas have been through decades of research and development $(\mathrm{R} \& \mathrm{D})$. They need decades more.

\section{Responsive regulation}

Law enforcers can be responsive to how effectively citizens or corporations are regulating themselves before deciding whether to escalate intervention. Responsive regulation is not something only governments do; civil society actors can also regulate responsivelyindeed, they can even regulate governments responsively (Gunningham et al. 1998). 
Responsive regulation requires us to challenge rulish presumptions that harmful conduct $\mathrm{X}$ mandates regulatory intervention $\mathrm{Y}$. If an armed robber is responding to the detection of her wrongdoing by turning around her life, kicking a heroin habit, helping victims and voluntarily working for a community group 'to make up for the harm she has done to the community' then the responsive regulator says no to imprisonment as an option mandated by a sentencing rule.

Therefore, many worry that responsive regulation is not designed to maximise consistency in law enforcement. The idea of responsive regulation grew from dissatisfaction with the business regulation debate. Some argue that businesspeople are rational actors who only understand the bottom line and who therefore must be consistently punished for law breaking. Others contend that businesspeople are responsible citizens who can be persuaded into compliance. In different contexts, there is truth in both positions. This means that both consistent punishment and consistent persuasion are foolish strategies. The hard question is how do we decide when to punish and when to persuade? What makes the question such a difficult one is that attempts to regulate conduct do not simply succeed or fail. Often they backfire, making compliance worse. So the tragedy of consistent punishment of wrongdoers of a certain type is that consistency causes regulators to make things worse for future victims of the wrongdoing.

\section{Pyramidal responsiveness}

The crucial point is that responsive regulation is a dynamic model in which persuasion and/or capacity building are tried before escalation up a pyramid of increasing levels of punishment. It is not about specifying in advance which are the types of matters that should be dealt with at the base of the pyramid, which are so serious that they should be in the middle and which are the most egregious for the peak of the pyramid. Even with the most serious matters, such as genocide in the Great Lakes region of Africa, responsive regulatory scholars have tended to stick with the presumption that it is better to start with dialogue at the base of the pyramid. A presumption means that, however serious the crime, our normal response is to try dialogue first for dealing with it and to override that presumption only if there are compelling reasons. Of course, there 
will be such reasons at times: the man who has killed one hostage and threatens to kill another may have to be shot without a trial, the assailant who vows to pursue the victim again and kill her should be locked up.

As we move up the pyramid in response to a failure to elicit reform and repair, we often reach the point where reform and repair are finally forthcoming. At that point, responsive regulation means that escalation up the pyramid is put into reverse and the regulator de-escalates down the pyramid. The pyramid is firm yet forgiving in its demands for compliance. Reform must be rewarded just as recalcitrant refusal to reform will ultimately be punished. Responsive regulation comes up with a way of reconciling the clear empirical evidence that punishment works sometimes and sometimes backfires, and likewise with persuasion (Braithwaite 1985; Ayres and Braithwaite 1992). The most systematic empirical exploration of the feasibility of these ideas can be found in 100 working papers of RegNet's Centre for Tax System Integrity (regnet.anu.edu.au/research/publications).

The pyramidal presumption of persuasion gives the more respectful option a chance to work first. Costly punitive attempts at control are thus held in reserve for the minority of cases where persuasion fails. Yet it is also common for persuasion to fail. When it does, a recurrent reason is that a business actor is being a rational calculator about the likely costs of law enforcement compared with the gains from breaking the law. Escalation through progressively more deterrent penalties will often take the rational calculator up to the point where it becomes rational to comply. Quite often, however, the business regulator finds that they try restorative justice and it fails; they try escalating up through more and more punitive options and they all fail to deter. Perhaps the most common reason in business regulation for successive failure of restorative justice and deterrence is that noncompliance is neither about a lack of goodwill to comply nor about rational calculation to cheat. It is about management not having the competence to comply. The manager of the nuclear power plant simply does not have the engineering knowhow to take on the level of responsibility asked of him. He must be moved from the job. Indeed, if the entire management system of a company is not up to the task, the company must lose its licence to operate a nuclear power plant. So when deterrence fails, the idea of the pyramid is that incapacitation is the next port of call (see Figure 7.1). 


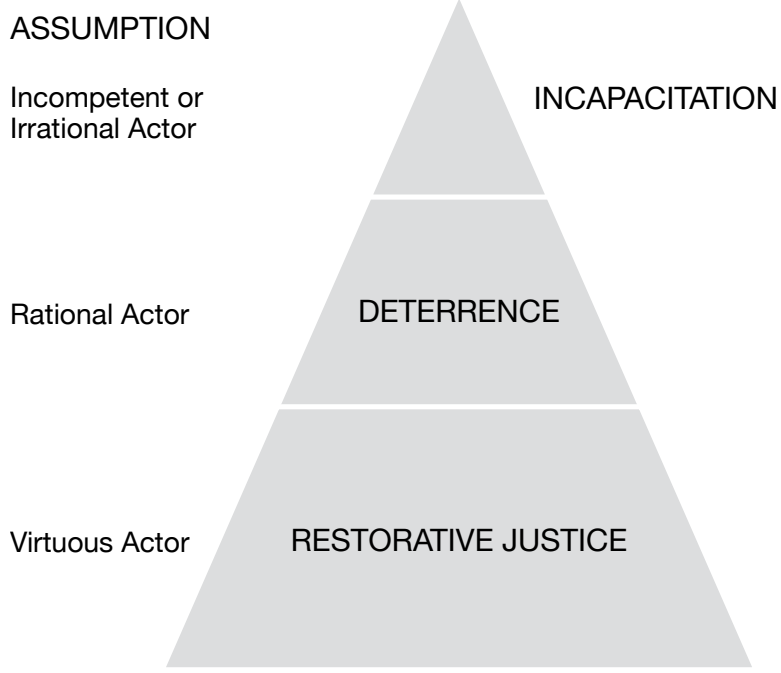

Figure 7.1 Integrating restorative, deterrent and incapacitative justice Source: Author's work.

This design responds to the fact that restorative justice, deterrence and incapacitation are all limited and flawed theories of compliance. What the pyramid does cover are the weaknesses of one theory and the strengths of another. The ordering of strategies in the pyramid is not just about putting the less costly, less coercive, more respectful options lower down to preserve freedom as nondomination (Pettit 1997). It is also that by resorting to more dominating, less respectful forms of social control only when dialogue has been tried first, coercive control comes to be seen as fair. When regulation is seen as more legitimate and more procedurally fair, compliance with the law is more likely (Murphy 2014). Astute business regulators often set up this legitimacy explicitly. During a restorative justice dialogue over an offence, the inspector says there is no penalty this time, but she hopes the manager understands that if she returns and finds the company has slipped back out of compliance again, under the rules, she will have no choice but to refer it to the prosecutions unit. When the manager responds, yes, this is understood, a future prosecution will likely be viewed as fair. Under this theory, therefore, privileging restorative justice at the base of the pyramid builds legitimacy and therefore compliance.

There is also a rational choice account of why the pyramid works. System overload results in a pretence of consistent law enforcement where, in practice, enforcement is spread around thinly and weakly. 
Unfortunately, this problem is worst where crime is worst. Hardened offenders learn that the odds of serious punishment are low. Tools such as tax audits that are supposed to be about deterrence frequently backfire by teaching hardened tax cheats how much they can get away with. Reluctance to escalate under the pyramid model means that enforcement has the virtue of being selective in a principled way. Moreover, the display of the pyramid itself channels the rational actor down to the base. Noncompliance comes to be seen (accurately) as a slippery slope that will inexorably lead to a sticky end. In effect, the pyramid solves the system capacity problem by making punishment cheap. The pyramid says unless you punish yourself for law breaking through an agreed action plan near the base of the pyramid, we will punish you much more severely higher up the pyramid (and we stand ready to go as high as needed). So it is cheaper for rational firms to punish themselves (as by agreeing to payouts to victims, community service or new corporate compliance systems). Once the pyramid accomplishes a world where most punishment is selfpunishment, there is no longer a crisis of the state's capacity to deliver punishment where needed. One of the messages of the pyramid is: if you keep breaking the law it is going to be cheap for us to hurt you because you are going to help us hurt you (Ayres and Braithwaite 1992: 44).

According to responsive regulatory theory, a good legal system is one in which citizens learn that responsiveness is the way institutions work. Once they perceive the system to be responsive, they know that there will be a chance to argue about unjust laws. They also see that gaming legal obligations and failure to listen to persuasive arguments about the harm their actions are doing and what must be done to repair it will inexorably lead to escalation. The forces of law are listening, fair and therefore legitimate, but also seen as somewhat invincible.

\section{Micro-responsiveness}

Development of responsive regulation was inductive. The ideas of responsive regulation and restorative justice-that because injustice hurts, justice should heal-as researched by RegNet's Centre for Restorative Justice (led by Heather Strang), were greatly influenced by conversations with coalmine and nursing home regulators. There was little originality, as what RegNet scholars did was distil the thinking of people considered master practitioners of regulation. 
The nursing home regulation data collection by Toni Makkai, Anne Jenkins, Diane Gibson, Valerie Braithwaite, John Braithwaite and others set out to test pre-existing theories rather than develop a new one. Valerie Braithwaite tested Kagan and Scholz's (1984) classic typology of regulated actors as political citizens, amoral calculators and incompetent. This was not the structure of reaction to regulatory authorities revealed in Braithwaite's (2009) factor analyses of the nursing home data or the subsequent tax data. The results that did emerge grounded her theory of motivational postures that became the micro-foundation for further R\&D of responsive regulation with the Australian Taxation Office (ATO). The motivational postures towards an authority were commitment to the authority and its rules, capitulation, resistance, game playing and disengagement. Responsiveness today is understood in terms of the variable requirements of responsiveness to individual and collective actors with these different motivational postures. These motivational postures are also being coded for 60 armed conflicts in 'Peacebuilding Compared', in which Valerie Braithwaite, John Braithwaite, Hilary Charlesworth, Adérito Soares, Bina D'Costa, Camille McMahon and other RegNet colleagues have been involved in seeking to understand what fails and succeeds in building sustainable peace.

The other important micro-foundation, developed in work on healthcare regulation by RegNet's Judith Healy (2011), has been on the need to complement a pyramid of sanctions with a pyramid of supports. Neil Gunningham and Darren Sinclair's (2002) work on the importance of leaders pulling laggards and environmental outcomes up through new ceilings also shaped the pyramid of supports idea.

\section{Networked, nodal responsiveness}

Peter Drahos (2004) more than tweaked the responsive regulatory pyramid to attune it to possibilities for networked regulation. In developing countries in particular, state regulators do not have the enforcement resources to escalate to one state regulatory strategy after another as each layer of the pyramid sequentially fails. The idea of the pyramid of networked escalation in Figure 7.2 is that a state regulator escalates by networking regulatory pressure from other actors-which can include other states (for example, the United States pressuring a foreign airline that puts US travellers at risk), international regulators, industry associations, hybrid industry-non-governmental organisation 
(NGO) certification organisations such as the Forest Stewardship Council, competitors, upstream and downstream corporate players in the supply chain of the problem actor and, most importantly, different media and civil society actors such as trade unions. Of course, civil society actors such as human rights groups can reflect responsively on how to deploy their own pyramid of networked escalation to enrol (Latour 1987) actors with more muscle than themselves in their regulatory projects (Braithwaite and Drahos 2000).

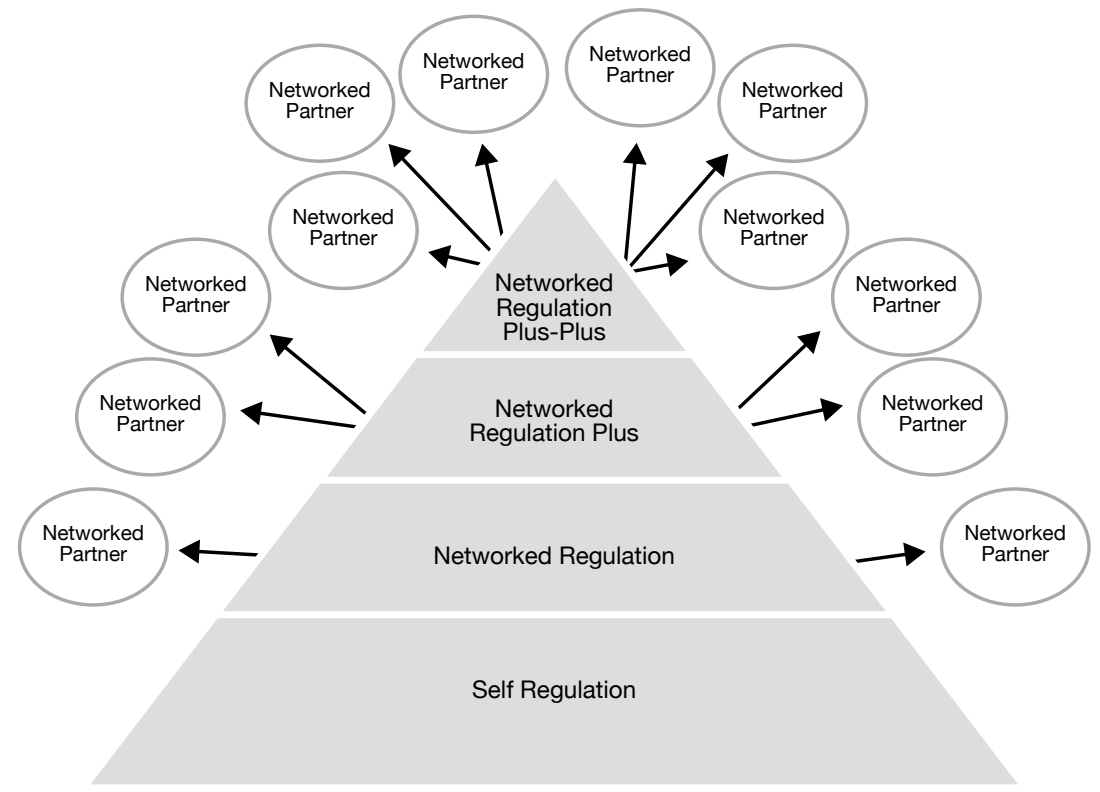

Figure 7.2 Drahos-esque networked escalation

Source: Author's work.

As combined use is made of pulling different kinds of levers wielded by different kinds of actors, the smart regulator attends to the many and various insights of Gunningham et al. (1998) into how some levers complement one another, while others are mutually incompatible, each defeating the purposes of the other. Smart regulation implies a diagnostically reflective regulator attending to the possible synergies and contradictions a pyramid of networked escalation can throw up.

A fair criticism of responsive regulation in theory and practice is that its emphasis on escalation up the pyramid when less interventionist strategies fail neglects refinement of tactics for de-escalation and lateral movement to more creative forms of networked regulation at the same 
level of the pyramid. Responsive regulation prescribes consideration of these options before escalation. Jennifer Wood and Clifford Shearing's (2007: 106-7) critique is that the pyramid can encourage the thought that if regulatory intervention fails, it is natural to escalate rather than scan laterally with fluidity and agility looking for horizontal problemsolving partners. When a restorative justice conference at one level of the pyramid fails, another conference that widens the circle to participants who bring new problem-solving resources into the circle is always an option, then another that widens it again. The Wood and Shearing critique commends special training in how to think more laterally and in less automatically escalatory ways. Hence, Braithwaite (2008: 99) proposed a set of corrective principles of responsive regulation that include never escalating to hard options without considering all available softer and horizontal interventions; using restorative dialogue to bubble up norm improvement, including law reform and radical deregulation; having a preference for 'governing by providing' over 'governing by regulating' and for capacity building over control; and scanning creatively and optimistically for potential network partners with fresh resources.

\section{Meta-regulatory responsiveness}

Enforced self-regulation was a founding idea of responsive regulation in the early 1980s. This was the notion that while self-regulation had the potential to harness the managerial creativity of a regulated industry to come up with cheaper and more effective means for achieving regulatory outcomes, self-regulation has a formidable history of industry abuse of this privilege. Peter Grabosky (1995; Gunningham et al. 1998) and Christine Parker (2002), among others, developed this theme in the more theoretically fruitful direction of meta-regulation. For regulation to become more resilient, attention was needed to how to make the regulation of regulation meaningful.

Some of the better-known meta-regulatory initiatives in enforcement practice have been disappointments. For example, US prosecutors negotiating Corporate Integrity Agreements in lieu of heavier corporate crime sentences deferred prosecutions while corporations put in place new internal compliance systems to prevent recurrence. These have been disappointing in the pharmaceutical industry, for instance, where firms like Pfizer have had one failed Corporate Integrity Agreement after another (Dukes et al. 2014: 339). A problem here is that 
prosecutors' offices are not regulatory bureaucracies. Specialist regulatory bureaucracies are better equipped to negotiate meaningful Corporate Integrity Agreements. They have superior knowledge of their domain of regulation than generalist prosecutors, because of their networking with compliance professionals and civil society (a special emphasis in Parker 2002) and with advocacy groups interested in monitoring that kind of miscreant corporation. Indeed, from a responsive regulatory perspective, best practice in the design of negotiated settlements has those third parties in the room. They participate when deals are proposed on the design of any Corporate Integrity Agreement or Enforceable Undertaking. With follow-through, the responsive ideal has always been that mandated independent reports on compliance with Enforceable Undertakings should be on a public register. These days, that means posted on the internet, where meta-regulators, who are competitors of the compliance professional who audited corporate compliance with the Enforceable Undertaking, can give the regulator a call to suggest that their competitor has done a methodologically shoddy or captured job of certifying compliance. Their interest in doing this is commercialto convince corporations in trouble with the law and regulators that they, rather than their competitors, are more trustworthy meta-regulators for ensuring that Enforceable Undertakings are exceeded rather than underdone. Without this, meta-regulatory laggards are the ones who will be rewarded rather than the leaders who take regulatory innovation up through new ceilings of excellence.

As with US Corporate Integrity Agreements, the Australian history with Enforceable Undertakings is littered with disappointments from the time of Brent Fisse's (1991) earliest attempts to reform them, yet also many successes that have occasionally transformed whole industries (such as the life insurance industry two decades ago: Fisse and Braithwaite 1993; Parker 2004). Some of the successes have been achieved with formidable follow-through by the relevant regulator. In the case of the transformation of insurance industry practices with disadvantaged consumers, prime minister Paul Keating asked for a briefing on what we were doing at the Trade Practices Commission to ensure that industry transformation occurred. Leading chief executive officers (CEOs) called press conferences to announce what they would do to achieve change for Aboriginal consumers and other disadvantaged consumers, and leading television current affairs programs followed through on those promises (Parker 2004). In short, successful meta-regulation is a bureaucratic accomplishment; prosecutors' offices are not regulatory bureaucracies. 
Prosecutors also have a different ethos from regulatory bureaucracies about what key performance indicators count. At worst, prosecutors are interested in counting notches on their gun.

The same regulator in Australia had some appalling experiences in negotiated settlements with big business, the most notorious being Robert McComas, chairman of the Trade Practices Commission, who came from being a director of Australia's largest tobacco company (and returned to chair its board). McComas negotiated a remedial advertisement with the Tobacco Institute that was as clearly a breach of his own statute as the initial advertisement complained about by Action Against Smoking and Health. It was an advertisement that claimed passive smoking was not proven to be a danger to health. The Australian Federation of Consumer Organisations (AFCO) appealed the commission's remedial advertisement. This was a brave decision by AFCO's young CEO, Robin Brown, who risked bankrupting AFCO had there been an order to pay the tobacco industry's costs. The Federal Court found the advertisement approved by the regulator to be in breach of its own statute because the evidence was clear that passive smoking was a danger to health. It was the first time anywhere in the world that a court made this finding. As soon as it did, risk managers across the globe started to advise restaurants, workplaces, discos and even sports grounds to prohibit smoking for fear of passive smoking suits. Such suits also started in Australia, citing that Federal Court decision. Surprisingly, even in the open air of baseball grounds in the land of the free, consumer self-enforcement through raised eyebrows quickly achieved 100 per cent compliance with these bans (Kagan and Skolnick 1993). It is hard to think of any case of responsive tripartism in Australian regulatory enforcement that might have saved more lives around the world. It was a case where the grunt of regulated self-regulation came from the consumer movement.

In the next decade, Brent Fisse started a debate on how to replace the kind of deals 'in smoke-filled rooms' of the passive smoking case with statutory provisions for Enforceable Undertakings that were susceptible to public checks and balances ratified/modified by a court. One crucial discussion among leading regulators in the early 1990s was led by Fisse and convened by The Australian National University (ANU) to shape this reform. Two decades later, most of Australia's important regulatory 
agencies have incorporated into their statutes Enforceable Undertaking provisions that were discussed at The Australian National University's University House that day.

The journey towards more meaningful meta-regulation in Australia continues to take steps backwards and forwards. Yet its strength is encapsulated by those meetings in Canberra on passive smoking and Enforceable Undertakings that delivered greater engagement of regulatory bureaucracies, greater public awareness and greater public scrutiny and greater third-party engagement with meta-regulation than seen with US prosecutors negotiating deferred prosecutions or Corporate Integrity Agreements.

\section{Socialist responsiveness}

Responsive regulation found markets to be institutions that could be harnessed and regulated to achieve outcomes that reduce domination (Pettit 1997). It conceived the past four decades as an era in which markets became stronger but so did regulation. It was an era of regulatory capitalism (Levi-Faur 2005; Braithwaite 2008).

I will never forget the first of a sequence of dozens of day-long meetings between 1983 and 1987 when treasurer Paul Keating and prime minister Bob Hawke argued in the Economic Planning Advisory Council (EPAC) that Australia should not only deregulate certain markets (including floating the dollar, which was quickly executed) but also privatise the national telecom provider, parts of the post office, the Commonwealth Bank, Qantas and many other state-owned enterprises. I was the most junior member of EPAC, representing consumer and community groups. The shock was that a Labor government was proposing such privatising reforms. I became convinced by the arguments for all of the initial privatising reforms (other more disastrous steps towards the commodification of higher education, for example, started later in 1988). The privatisation of Qantas was the one that most worried some of us initially. Arguments of some persuasiveness were advanced that Qantas had a better safety record than private US airlines, indeed, than any airline in the world, partly because it was a public enterprise. The government responded with assurances to strengthen air safety regulation. 
In the event, Qantas, at least for its first decade or two as a private enterprise, continued to have a very good safety record; indeed, after privatisation, it was the first airline in the world to introduce certain safety technologies such as new-generation radar. Still, the worry remains that in the history of capitalism, public enterprise has taken safety practice up through ceilings of excellence that corner-cutting private enterprises would never have secured. In the middle decades of the twentieth century, British coalmines became much safer than Australian or US coalmines (Braithwaite 1985: 76-7). Some analysts (Turton 1981; Braithwaite 2013) and even the US General Accounting Office (1981) diagnosed great leaps forward in coalmine safety as being caused by the nationalisation of the coal industry in Britain from 1946. A good number of rapacious mining magnates were replaced with professional managers who invested in safety self-regulation, empowered the National Union of Mine Workers and invested in R\&D into how to make mines safer. Interviews at Charbonnages de France in France in 1981 also led me to suspect that they and other European nationalised coal industries also made strategic global contributions to making mines safer.

In the West, the era of nationalised coal is long gone, as, hopefully, an era of leaving coal in the ground approaches. Yet under global privatisation of coal, the safety gains of nationalised coal were not lost. Continuing progress in improving the safety of mines was internalised as part of the social licence that privatised coal had to satisfy. Jody Freeman (2003) might say that privatised coal had been publicised by public law values, particularly about stakeholder voice in their own safety, during the socialist interregnum of coal production systems. Progress has continued apace in the safety of Western coal production, though it has been set back by authoritarian capitalist coal production from China to the Democratic Republic of Congo. In the West, strategic socialism was a kind of circuit-breaker on the road to a more civilised capitalism. This case study of regulatory capitalism might be a clue for more focus on the possibilities for temporary socialism as a path to a less destructive capitalism.

Elsewhere, Braithwaite (2013) argued that Europe should have established a socialist ratings agency after the 2008 Global Financial Crisis to compete with Moody's and Standard \& Poor's, and argued for states owning shares in banks they bail out, which they then sell when banks return to profitability. Today the imperative for strategic socialist shifts away from markets is as strong as it was during the strategic 
privatisations of the 1980s. Universities as a key site for doing regulatory analysis represent a crucial node for that struggle for public value, for a gift economy that trumps a market economy where it is important to do so. That is why RegNet prioritised pro bono work in its values statement. RegNet has been in the business of seeking to persuade ANU that giving universities attract even bigger gifts, while universities that are on the take reap a bitter harvest.

\section{Conclusion}

Types of responsiveness considered here complement many others that might have been detailed in a longer essay. Normative dimensions of responsiveness are a particularly important omission-such as domination responsiveness in the work of scholars like Philip Pettit and his collaborators and rights and feminist responsiveness in the work of Hilary Charlesworth and her collaborators, among others.

The responsiveness frames listed have been enough to illustrate the way that responsive regulation is not a tightly prescriptive theory. Rather it pushes us to see regulation as central to the kind of regulatory capitalism of this century. The suggestion of this chapter is that we might only see the dangers and opportunities in regulatory capitalism by picking up multiple responsiveness lenses, including consideration of pyramidal responsiveness, then micro-responsiveness to motivational postures, then networked responsiveness, then socialist and meta-regulatory responsiveness to regulatory capitalism.

Networks of scholars have worked on all these lenses, most from beyond ANU. RegNet has perhaps been a noteworthy node in that R\&D. It has not made this contribution with a few stars, but by 60 RegNet networkers across 17 years. PhD scholars made some of RegNet's best contributions, as did research officers and regulatory practitioners who became $\mathrm{PhD}$ graduates, of which there have been many. Jenny Job's leadership on responsive regulation in the ATO and Safe Work Australia, her work as a RegNet research officer and then a brilliant $\mathrm{PhD}$ on a micro-macro theory of social capital and responsive tax system integrity are fine examples. Another is Liz Bluff, who, as a RegNet research officer, built, with Richard Johnstone, Neil Gunningham and Andrew Hopkins, the National Research Centre for Occupational Health and Safety Regulation with a large network of scholars and practitioners beyond ANU. Liz 
completed her PhD and is now a Research Fellow at RegNet. Michelle Burgiss-Kasthala worked at that centre even before Liz, completed an exciting $\mathrm{PhD}$ on architectural regulation (walls) in international affairs, moved to a lectureship at St Andrews University for some years and is now back at RegNet as an Australian Research Council (ARC) Fellow. There are many others whose contributions have been their equal.

Responsive regulation is about listening to the wisdom of practitioners in regulatory agencies, business and advocacy groups to discover deep structures of theoretical meaning in their struggles. At the various ANU and Canberra meetings on passive smoking enforcement and on Enforceable Undertakings statutes, and at the 1983-87 meetings of the National Economic Summit and EPAC in the Cabinet room that helped refine Hawke-Keating regulatory capitalism, scholars did not count among the most important voices or sources of ideas. The idea of responsive regulation and the idea of RegNet is that wisdom grounded in practice leads theory; then that theory provides better lenses through which to see and transform practice. The gifts we scholars give, at their best, add a little yeast to that noble process.

\section{Further reading}

Adams, P and Chandler, SM 2004. 'Responsive regulation in child welfare: Systemic challenges to mainstreaming the family group conference', Journal of Sociology and Social Welfare 23(1): 93-110.

Braithwaite, J, Makkai, T and Braithwaite, V 2007. Regulating Aged Care: Ritualism and the New Pyramid. Cheltenham, UK: Edward Elgar. doi.org/10.4337/9781847206855.

Braithwaite, V 2006. Ten things you need to know about regulation and never wanted to ask, Occassional Paper No. 10, Regulatory Institutions Network, Canberra. Available at: regnet.anu.edu.au/ research/publications/3566/no-10-ten-things-you-need-knowabout-regulation-and-never-wanted-ask.

\section{References}

Ayres, I and Braithwaite, J 1992. Responsive Regulation. Oxford: Oxford University Press. 
Braithwaite, J 1985. To Punish or Persuade? Albany, NY: State University of New York Press.

Braithwaite, J 2008. Regulatory Capitalism: How it Works, Ideas for Making it Work Better. Cheltenham, UK: Edward Elgar. doi. org/10.4337/9781848441262.

Braithwaite,J 2013.'Strategic socialism, strategic privatization and crises', Australian Journal of Corporate Law 28: 35-59. doi.org/10.2139/ ssrn.2249544.

Braithwaite, J and Drahos, P 2000. Global Business Regulation. Cambridge: Cambridge University Press.

Braithwaite, V 2009. Defiance in Taxation and Governance. Cheltenham, UK: Edward Elgar. doi.org/10.4337/9781848449077 .

Drahos, P 2004. 'Intellectual property and pharmaceutical markets: A nodal governance approach', Temple Law Review 77(2): 401-24.

Dukes, G, Braithwaite, J and Maloney,J 2014. Pharmaceuticals, Corporate Crime and Public Health. Cheltenham, UK: Edward Elgar. doi. org/10.4337/9781783471102.

Fisse, B 1991. 'Recent developments in corporate criminal law and corporate criminal liability to monetary penalties', Recent Developments in Corporate Criminal Law 13(1): 1-41.

Fisse, B and Braithwaite, J 1993. Corporations, Crime and Accountability. Cambridge: Cambridge University Press.

Freeman, J 2003. 'Extending public law norms through privatization', Harvard Law Review 16: 1285-91. doi.org/10.2307/1342728.

General Accounting Office 1981. Low Productivity in American Coal Mining. Washington, DC: General Accounting Office.

Grabosky, P 1995. 'Using non-governmental resources to foster regulatory compliance', Governance 8(4): 527-50. doi. org/10.1111/j.1468-0491.1995.tb00226.x.

Gunningham, N, Grabosky, P and Sinclair, D 1998. Smart Regulation: Designing Environmental Policy. Oxford: Clarendon Press. 
Gunningham, N and Sinclair, D 2002. Leaders and Laggards: NextGeneration Environmental Regulation. Sheffield: Greenleaf Publishing.

Healy, J 2011. Improving Health Care Safety and Quality: Reluctant Regulators. Farnham, UK: Ashgate.

Kagan, RA and Scholz, JT 1984. 'The criminology of the corporation and regulatory enforcement strategies', in K Hawkins and J Thomas (eds), Enforcing Regulation. The Hague: Kluwer-Nijhoff, pp. 352-77. doi.org/10.1007/978-94-017-5297-8_4.

Kagan, RA and Skolnick, J 1993. 'Banning smoking: Compliance without enforcement', in R Rabin and S Sugarman (eds), Smoking Policy. New York: Oxford University Press, pp. 69-94.

Latour, B 1987. Science in Action. Buckingham: Open University Press.

Levi-Faur, D 2005. 'The global diffusion of regulatory capitalism', Annals of the American Academy of Political and Social Science 598: 12-32. doi. org/10.1177/0002716204272371.

Murphy, K 2014. 'Turning defiance into compliance with procedural justice', Regulation EF Governance 10(1): 93-109. doi.org/10.1111/ rego.12073.

Parker, C 2002. The Open Corporation. Cambridge: Cambridge University Press. doi.org/10.1017/CBO9780511550034.

Parker, C 2004. 'Restorative justice in business regulation? Australian competition use of enforceable undertakings', Modern Law Review 67: 209-46. doi.org/10.1111/j.1468-2230.2004.00484.x.

Pettit, P 1997. Republicanism. Oxford: Oxford University Press.

Turton, FB 1981. 'Colliery explosions and fires: Their influence upon legislation and mining practice', Mining Engineer (September): 157-64.

Wood, J and Shearing, C 2007. Imagining Security. Cullompton, UK: Willan Publishing. 
This text is taken from Regulatory Theory: Foundations and applications, edited by Peter Drahos, published 2017 by ANU Press, The Australian National University, Canberra, Australia. 